\title{
Adiposopathy and Obesity Paradox
}

\author{
Indriyanti Rafi Sukmawati $^{1,2, *}$, Andi Wijaya ${ }^{1,3}$ \\ ${ }^{1}$ Postgraduate Program in Clinical Biochemistry, Hasanuddin University, Jl. Perintis Kemerdekaan Km.10, Makassar, Indonesia \\ ${ }^{2}$ Prodia Clinical Laboratory, Jl. Kramat Raya No.150, Jakarta, Indonesia \\ ${ }^{3}$ Prodia Clinical Laboratory, Jl. Cisangkuy No.2, Bandung, Indonesia \\ *Corresponding author. E-mail: indriyanti.rs@prodia.co.id
}

\section{Abstract}

$\mathrm{B}$ ACKGROUND: Obesity has reached global epidemic proportions in both adults and children and is associated with numerous comorbidities, including hypertension, type 2 diabetes mellitus (T2DM), dyslipidemia and major cardiovascular diseases (CVD).

CONTENT: Adiposity may cause adipocyte and adipose tissue anatomic and functional abnormalities, termed adiposopathy (adipose-opathy) or "sick fat," that result in endocrine and immune derangements. Adiposopathy may directly contribute to CVD through pericardiac and perivascular effects on the myocardium and blood vessels. Adiposopathy may also indirectly contribute to CVD through promoting or worsening major CVD risk factors such as T2DM, high blood pressure, and dyslipidemia. Despite this adverse association, numerous studies have documented an obesity paradox in which overweight and obese people with established CVD, including hypertension, heart failure, coronary heart disease, and peripheral arterial disease, have a better prognosis compared with nonoverweight/ nonobese patients. These paradoxical findings are made less paradoxical when the pathogenic potential of excessive body fat is assessed based on adipose tissue dysfunction rather than simply on increased fat mass alone.

SUMMARY: Adiposopathy is defined as pathological adipose tissue function that may be promoted and exacerbated by fat accumulation (adiposity) and sedentary lifestyle in genetically susceptible patients. Adiposopathy is a root cause of some of the most common metabolic diseases observed in clinical practice, including T2DM, hypertension and dyslipidemia.

KEYWORDS: adiposopathy, adiposity, obesity

\section{Abstrak}

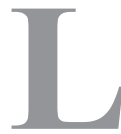

ATAR BELAKANG: Obesitas telah mencapai epidemis secara global, baik pada anak maupun dewasa, dan obesitas berkaitan dengan berbagai komorbiditas meliputi hipertensi, diabetes melitus tipe 2 (DMT2), dislipidemia, dan penyakit kardiovaskular (PKV) mayor.

ISI: Adipositas dapat menyebabkan abnormalitas sel adiposit dan jaringan adiposa baik secara anatomi maupun fungsional, dan hal ini dikenal sebagai adiposopati (adiposaopati), atau "lemak yang sakit", yang menyebabkan gangguan sistim endokrin dan imun. Adiposopati dapat berperan langsung terhadap PKV melalui efek pericardiac dan perivaskular pada otot jantung dan pembuluh darah. Adiposopati juga dapat mempengaruhi PKV secara tidak langsung dengan cara memperburuk faktor risiko PKV seperti DMT2, hipertensi, dan dislipidemia. Selain hubungan yang merugikan ini, banyak penelitian yang membuktikan suatu paradoks obesitas dimana subyek dengan kelebihan berat badan atau obesitas yang juga menderita PKV, termasuk hipertensi, gagal jantung, penyakit jantung koroner, dan penyakit arteri perifer, menunjukkan prognosis yang lebih baik dibandingkan dengan pasien tanpa kelebihan berat badan/obesitas. Penemuan paradoks ini menjadi kurang berarti jika kajian potensi patogenik kelebihan lemak tubuh didasarkan pada disfungsi jaringan lemak dan bukan pada peningkatan massa lemaknya saja.

RINGKASAN: Adiposopati didefinisikan sebagai disfungsi jaringan lemak yang patologis, dan dapat dipicu serta diperburuk oleh akumulasi lemak (adipositas) dan gaya hidup sedentary, pada pasien yang rentan secara genetik. Adiposopati merupakan akar penyebab berbagai penyakit metabolik yang ditemukan secara klinis, seperti DMT2, hipertensi dan dislipidemia. 
paradox, adipocyte dysfunction, adipose hypertrophy, adiposehyperplasia
KATA KUNCI: adiposopati, adipositas, paradoks obesitas, disfungsi adiposit, hipertrofi adiposa, hiperplasia adiposa

Indones Biomed J. 2013; 5(1): 3-12

\section{Introduction}

Obesity is an epidemic. An increase in body fat in many individuals and populations directly increases the risk of metabolic diseases such as type 2 diabetes mellitus (T2DM), hypertension and dyslipidemia.(1,2) The increased prevalence of excessive visceral obesity and obesity related cardiovascular risk factors is closely associated with the rising incidence of cardiovascular diseases (CVD) and T2DM. This clustering of vascular risk factors in (visceral) obesity is often referred to as metabolic syndrome.(3-5)

However, obesity itself is not yet universally recognised as a disease. A sole focus on body mass index (BMI) in attempting to define obesity as a disease is not adequate. A more rational approach is to evaluate excessive body fat for its pathogenic potential. This requires recognising that adipose tissue is an active endocrine and immune organ, and that pathological disruption of important adipose tissue metabolic processes is detrimental to patient health.(6-8) The failure to adequately recognise the physiologic importance of adipose tissue to metabolic health, both clinically and in the medica/endocrine literature, is significantly because of a failure of existing terminology to adequately describe the pathogenic potential of adipose tissue, and its contribution to metabolic disease.(9)

From a pathophysiological point of view, the 'quality' of adipose tissue is more important than the 'quantity'. Nevertheless, a major driver of adipose tissue function is the quantity of visceral fat.(10) 'Adiposopathy' (adiposeopathy) is a term used to describe the adverse anatomical and pathophysiologic consequences of pathogenic adipose tissue. From a patient standpoint, the term adiposopathy can be translated as representing 'sick fat'.(11) These terms and this approach emphasise that adipose tissue has as much pathogenic potential to result in ill health as the pathologic dysfunction of other body tissues. Thus, 'adiposopathy' represents a 'disease' similar to other organopathies.(9) Although obesity has been implicated as one of the major risk factors for hypertension, heart failure (HF) and coronary heart disease (CHD), evidence from clinical cohorts of patients with established CVD indicates an obesity paradox because overweight and obese patients with hypertension, $\mathrm{HF}, \mathrm{CHD}$, and peripheral arterial disease (PAD) tend to have a more favorable short and longterm prognosis.(12)

\section{Obesity}

The etiology of obesity is multifactorial. However, the root cause is energy imbalance: more calories consumed than expended. Chronic imbalance of calories consumed vs expended causes increased storage of the excess energy in the form of adipocyte intracellular triglyceride stores. The increase in fat mass manifests as both increased intracellular lipids and greater adipocyte size (hypertrophy) and increased numbers of adipocytes (hyperplasia).(13)

During the past 10 years, the understanding of the physiological and pathophysiological role of the adipocyte has been completely changed. Once considered to be a passive type of connective tissue storing excess energy as triglycerides, adipose tissue has now been established as a real endocrine organ coupling (neuro)-endocrine and metabolic signaling.(14) Secretory products of preadipocytes and mature adipocytes, the so-called adipocytokines, clearly regulate energy homeostasis, appetite/satiety, reproduction, and insulin sensitivity and influence neuroendocrine, endothelial, immunological, hematological, angiogenetic, and vascular functions in an endocrine, paracrine, and autocrine manner.(15)

Adipocytes typically constitute the majority of adipose tissue cellular content. Fat containing adipocytes constitute, by far, most of the adipose tissue volume. Adipocytes are surrounded by fibrous connective tissue, collagen, nerves, and blood vessels. Adipose tissue's supporting framework contains "stromal vascular fraction" cells, which include mesenchymal cells, fibroblasts, preadipocytes, endothelial precursor cells, smooth muscle cells, blood cells, and immune cells.(16) Previously, adipogenesis was thought to cease early in life, resulting in a fixed number of adipocytes that predestined individuals to be lean or obese. However, fat cell turnover is now known to be a dynamic process by which mesenchymal stem cells undergo lineage commitment, preadipocyte proliferation, growth arrest, and terminal differentiation into mature adipocytes. The number of adipocytes is therefore dependent on the balance between adipogenesis and apoptosis(17,18), with some suggesting that approximately $10 \%$ of fat cells are renewed annually at all adult ages and at all levels of body mass index (BMI).

This has clinical implications because during 
positive caloric balance, adipocytes normally undergo initial hypertrophy, which elicits cellular signaling for the recruitment, proliferation, and differentiation of new fat cells. If adipogenesis proceeds unencumbered in peripheral subcutaneous adipose tissue, then adiposity may not cause demonstrable adipose tissue dysfunction or adverse metabolic consequences. Conversely, if adipogenesis is impaired, then the lack of adipocytes to adequately proliferate (or differentiate) may be pathophysiologically analogous to a relative lack of adipocytes, sometimes described as representing an acquired lipodystrophy.(20) The lack of excess energy storage in new fat cells due to inadequate adipogenesis may cause existing fat cells to undergo excessive hypertrophy, causing adipocyte dysfunction and pathogenic adipocyte and adipose tissue endocrine and immune responses. $(6,21)$

Adipocytes become hypertrophic during the development of obesity, and their size increases up to 140$180 \mu \mathrm{m}$ in diameter. Adipocytes have a limited capacity for hypertrophy; one reason for this is considered the diffusion limit of oxygen, which is at most $100 \mu \mathrm{m}$. Therefore, it is possible that hypertrophic adipocytes might endure less than adequate oxygen supply.(22,23) Hypoxia occurs when oxygen availability does not match the demand of the surrounding tissue, resulting in decreased oxygen tension. (24) An important and well characterized key regulator of the adaptive response to alterations in oxygen tension is hypoxia-inducible factor 1 (HIF1), a transcription factor that accumulates during hypoxia and increases the mRNA expression of a wide variety of genes that stimulate erythropoiesis, angiogenesis, and glycolysis.(25) Many disturbances including hypoxia cause accumulation of unfolded proteins in the endoplamic reticulum (ER), resulting in ER stress.(26)

Thus, in states of energy imbalance and adiposity, excessive demands on the ER result in dysfunction of protein folding, lipid-droplet creation, and cholesterol sensing. Manifestations of adipocyte ER stress include increased lactate concentrations and production of CCAT/ enhancer binding protein $(\mathrm{C} / \mathrm{EBP})$ homologous protein (CHOP). In mouse models, CHOP decreases production of adiponectin, and interfering with $\mathrm{CHOP}$ mRNA counteracts this decrease in adiponectin(24), providing insight into how intraorganelle dysfunction may be communicated systemically via circulating adipokines. Another cellular manifestation of ER stress is the "unfolded protein response" (UPR).(13) This state of ER stress, manifested by increased lactate, CHOP production, and activation of UPR, also may result in systemic release of free fatty acids and inflammatory mediators. (27) In short, if during positive caloric balance, any stage of the adipogenic processes is impaired (recruitment, proliferation(28) or differentiation(29-31), then this may lead to pathologic adipose tissue endocrine and immune responses that contribute to metabolic disease, particularly in individuals who are genetically or environmentally predisposed.(6)

\section{Obesity Paradox}

Large studies of initially healthy men and women consistently link adiposity with an increased risk of cardiovascular events. $(32,33)$ Compared with a reference body mass index (BMI), $<25 \mathrm{~kg} / \mathrm{m}^{2}$, the relative risk of dying during the next decade ranges from 1.2 for over weight $\left(25-29.9 \mathrm{~kg} / \mathrm{m}^{2}\right)$ to 3.8 for severely obese ( $>40 \mathrm{~kg} /$ m2) subjects, after adjustment for age, smoking, alcohol and physical activity.(32) In striking contrast, among patients with known atherothrombotic diseases $(34,35)$ or multiple risk factors(36), just the opposite is seen ('obesity paradox'): the leanest fare worse(34) and the heavier fare better than the normal weight reference groups.(34-36)

Obesity, hypertension, and the obesity paradox, despite having a higher prevalence of hypertension in obesity, recent data have shown an obesity paradox. Uretsky et al. investigated the effects of obesity on cardiovascular outcomes in 22,576 treated hypertensive patients with known CHD.(34) During 2-year follow up, all-cause mortality was $30 \%$ lower in overweight and obese patients, despite less effective blood pressure control in these patients compared with the normal weight group. A previous study also showed decreased stroke risk and total mortality among overweight patients compared with lean patients. (37) Similarly, another major hypertension study showed a U-shaped relationship between all cause, cardiovascular, and non cardiovascular mortality and BMI, meaning excess mortality at both extremes of BMI.(38) In another study of 800 elderly hypertensive patients, total mortality and cardiovascular and non cardiovascular major events were highest in those with the leanest BMI quintile.(39) The association between BMI and major cardiovascular events was U-shaped, whereas non cardiovascular mortality decreased with increasing BMI. In aggregate, these studies suggest that although obesity may be a powerful risk factor for hypertension and left ventricular hypertrophy (LVH), obese hypertensive patients may paradoxically have a better prognosis, possibly because of having lower systemic vascular resistance and plasma renin activity compared with more lean hypertensive patients. $(12,40)$

Obesity, HF, and the obesity paradox, in a study of 5,881 Framingham Heart Study participants, Kenchaiah 
et al. showed that during a 14-year follow-up, for every 1 $\mathrm{kg} / \mathrm{m}^{2}$ increment in BMI, the risk of HF increased 5\% in men and $7 \%$ in women. In fact, a graded increase in the risk of HF was observed across all categories of BMI.(12,41) Despite the known adverse effects of obesity on both systolic and particularly diastolic cardiovascular function and the epidemiologic data showing a strong link between obesity, generally defined by BMI criteria, and HF, many studies have suggested that obese HF patients had a better prognosis (Figure 1).(42) In a recent meta-analysis of 9 observational HF studies $(n=28,209)$ in which patients were followed up for an average of 2.7 years, Oreopoulos et al., showed that compared with individuals without elevated BMI, overweight and obese HF patients had reductions in cardiovascular (19 and 40\%, respectively) and reduction all cause mortality 16 and 33\% respectively.(43)

Obesity, CHD, and the obesity paradox, obesity plays a major role in adversely affecting major CHD risk factors, including hypertension, dyslipidemia, and T2DM, is the major component of metabolic syndrome, and is probably an independent risk factor for atherosclerosis and CHD events.(41,44-46) Nevertheless, as with hypertension and HF, many studies have also reported an obesity paradox in $\mathrm{CHD}$, including in patients treated with revascularization $(44,47)$.

In a recent systematic review of over 250,000 patients in 40 cohort studies followed up for 3.8 years, RomeroCorral et al. reported that overweight and obese CHD patients have a lower risk for total and cardiovascular mortality compared with underweight and normal-weight CHD patients. $(12,47)$ Importantly, the obesity paradox has also been shown in patients after myocardial infarction and revascularization, and more recently has been shown in patients referred for exercise stress testing. $(47,48)$ Although the mechanism for this effect is uncertain, in aggregate, these studies suggest that despite the fact that obesity increases the risk for developing CHD, at least overweight and mild obesity do not seem to adversely affect prognosis in patients with established CHD.(12)

Obesity paradox in other cardiovascular populations. Galal et al., have recently assessed 4.4 year mortality in 2,392 patients with PAD who had undergone major vascular surgery and had high mortality risk during followup. This study also showed a powerful obesity paradox, with progressive reductions in mortality in normal BMI, overweight, and obese groups compared with underweight patients.(12,49)

Although it is debated to what extent diabetes, sedentary lifestyle, hypertension, and dyslipidemia (often associated with adiposity and not always corrected for in

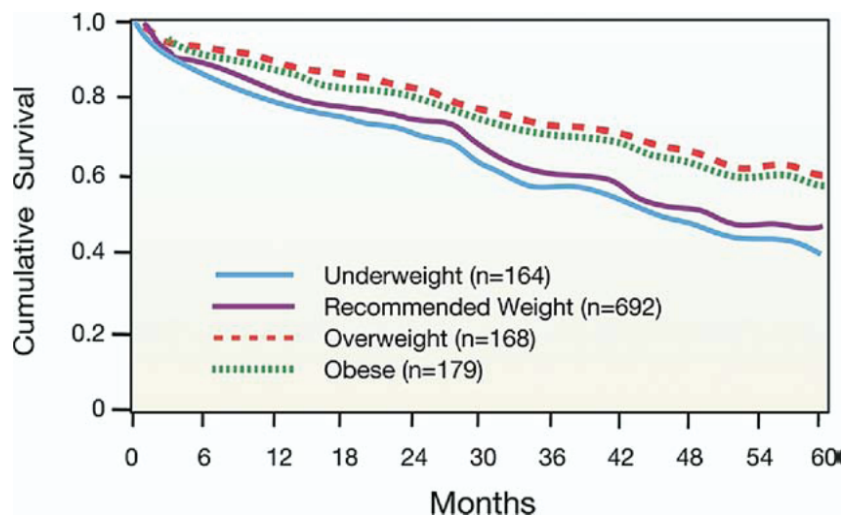

Figure 1. Risk-adjusted survival curves for the 4 body mass index categories at 5 years in a study of 1,203 individuals with moderate to severe HF.(12) (Adapted with permission from Elsevier Inc.).
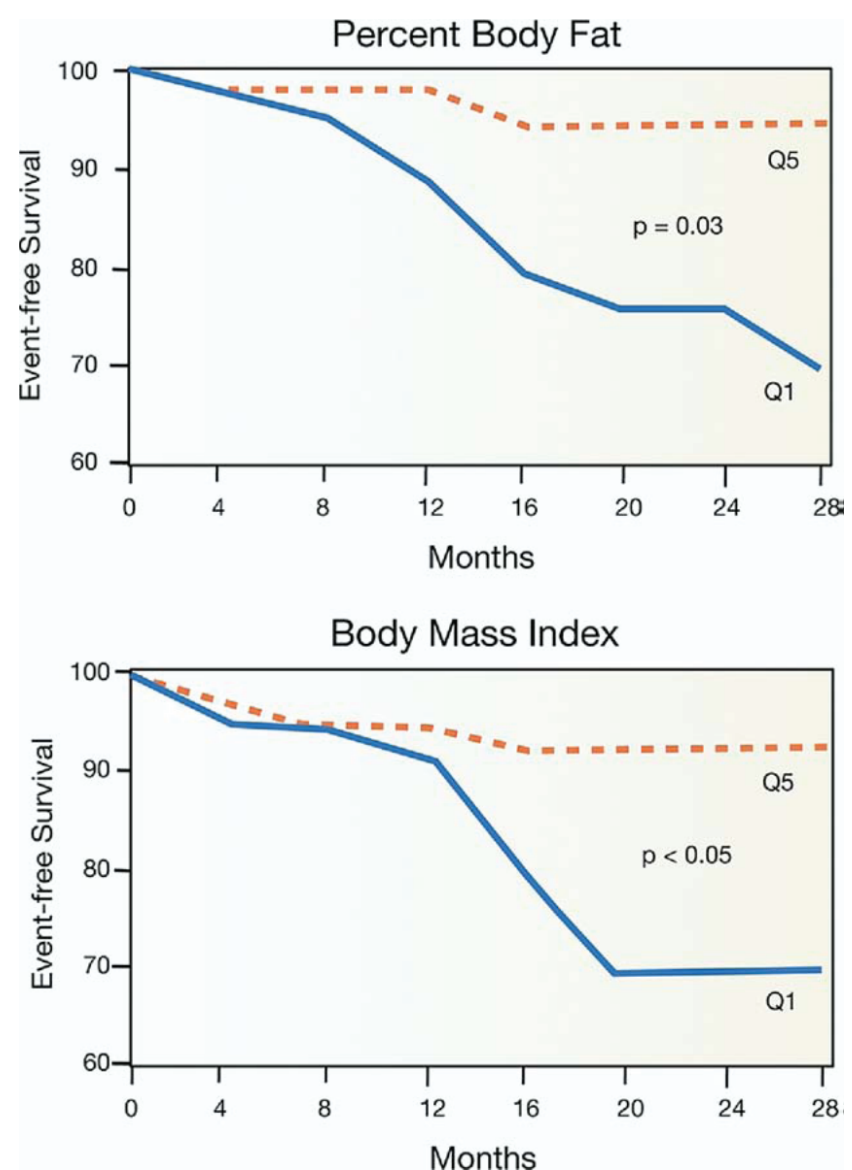

Figure 2. Body Composition and HF Prognosis.(12) (Adapted with permission from Elsevier Inc.)

data analyses) contribute to cardiovascular risk, fatness remains a strong harbinger of cardiovascular events among initially healthy subjects, especially when co-inflammation favours the 'unhealthy fat' phenotype (Figure 3). $(50,51)$ At the same time, adipose tissue, while increasing the probability of developing atherothrombosis, may offer protection in the context of tissue damage, supporting the aphorism 'survival of the fattest'. Possible defences conferred by adiposity include regenerative, metabolic, and 
haemodynamic compensation, and/or reversal to a 'healthy fat' phenotype (Figure 3). Thus, a condition signalling risk would confer protection in the midst of disease, just as pre-infarction unstable angina, while heralding thrombotic complications, protects myocardium against prolonged ischaemia. $(34,51,52)$

Overwhelming evidence supports the importance of obesity in the pathogenesis and progression of CVD. Although an obesity paradox exists, in that overweight and obese patients with established CVD seem to have a more favorable prognosis than leaner patients, the constellation of data still support purposeful weight reduction in the prevention and treatment of CVD.(12)

\section{Adiposopathy}

Adiposity is excessive adipose tissue. Those with adiposity are characterized as being overweight or obese. Obesity is described as an independent risk factor for CVD. Adiposity is pathological to the cardiovascular system through excessive fat-mass mechanisms and through adipocyte and adipose tissue dysfunction. $(6,16)$ Adipose tissue may be pathogenic though the adverse consequences of excessive fat mass alone, and/or though deleterious endocrinologic and immunologic activity. Adipocyte hyperthrophy and viceral adipose tissue accumulation are ascocieted with many of the most common metabolic disease found in clinical practice, including T2DM, hypertension, dyslipidemia and possibly atherosclerosis. $(53,54)$

"Disease" can be defined as an impairment of body function or system, often accompanied by pathological alterations in tissues or cell, resulting in adverse clinical outcomes.(55) If adipocyte hypertropthy and visceral adipose tissue accumulation occur during positive caloric balance, then the pathogenic consequences may unfavorably affect other body organs, such as liver, muscle, and pancreas, resulting in adverse clinical outcomes.(2) It is, therefore, through the understanding of the pathogenic potential of hypertrophied adipocytes and increased accumulation of visceral adipose tissue that helps support how an increase in body fat, in many individuals, is itself a disease. It also provides a framework for explaining why treating pathogenic adipose tissue is more rational than treating BMI alone.(8)

It was through decades of adipose tissue scientific research and the acknowledgment of the importance of central adiposity by major scientific organizations that the term "adiposopathy" arose.(11) Cardiomyopathy describes the pathologic enlargement of heart cells and the heart organ, which results in anatomic/functional abnormalities leading to adverse clinical consequences. Similarly, adiposopathy describes the pathogenic enlargement of fat cells and fat tissue, which results in anatomic/functional abnormalities leading to adverse clinical consequences, including the most common metabolic diseases encountered in clinical practice (e.g., T2DM, high blood pressure, dyslipidemia).(56)

Adiposopathy (or "sick fat") is defined as pathologic adipose tissue anatomic/functional disturbances promoted by positive caloric balance in genetically and environmentally susceptible individuals that result in adverse endocrine and

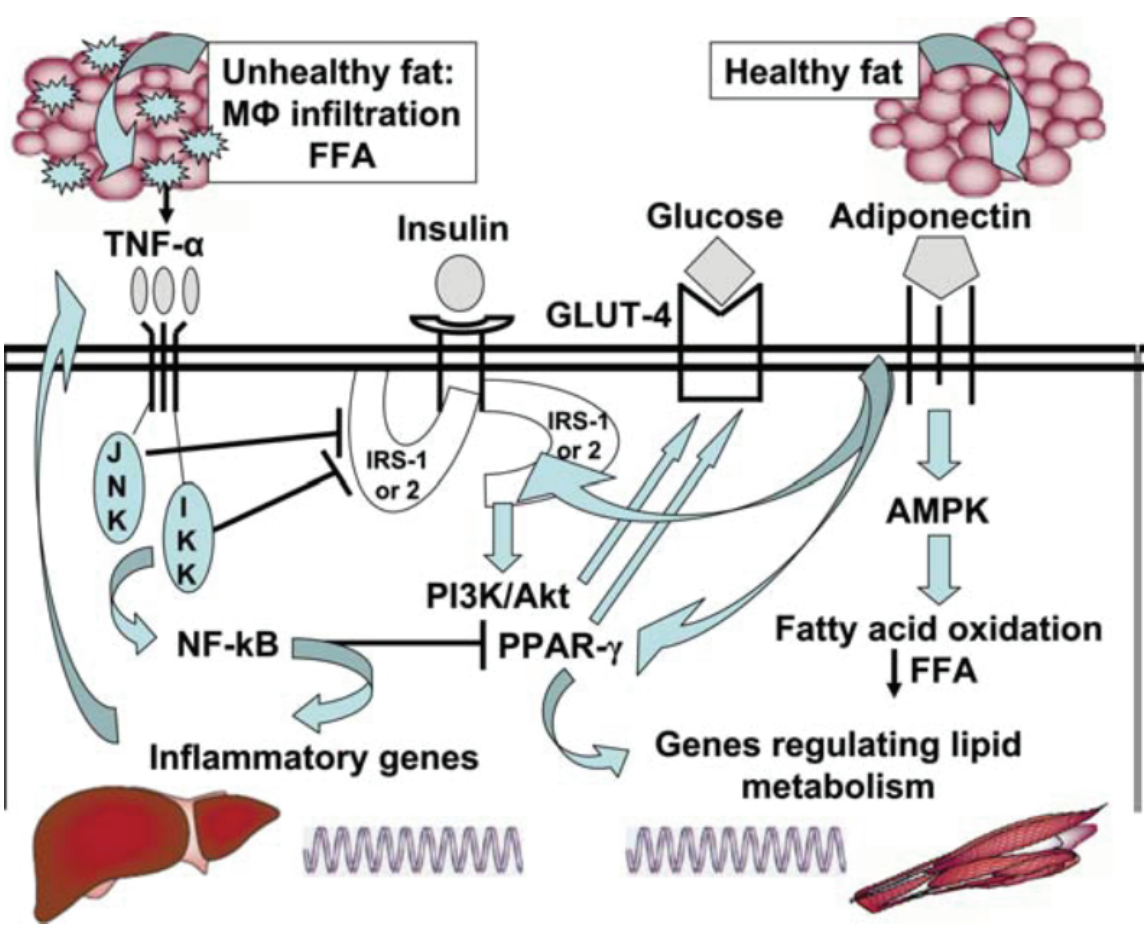

Figure 3. Unhealthy vs healthy fat phenotype.(15) (Adapted with permission from European Society of Cardiology) 
immune responses that may directly promote CVD, and may cause or worsen metabolic disease. Because many of these metabolic diseases are major CVD risk factors (e.g., T2DM, high blood pressure, and dyslipidemia), adiposopathy also indirectly increases CVD risk.(21)

Adiposopathy is anatomically manifested by adipocyte hypertrophy, visceral adiposity and/or ectopic fat deposition, which physiologically results in adverse endocrine and immune consequences leading to metabolic disease.(9) The clinical importance of adiposity is not only how fat is stored (i.e., adipocyte proliferation vs. adipocyte hypertrophy), but also where fat is stored. Visceral adipose tissue may be more metabolically active than subcutaneous adipose tissue, and these depots inherently differ in processes involving lipolysis/lipogenesis, expression of adipocyte receptors, and differ in the secretion of adipokines/cytokines, enzymes,

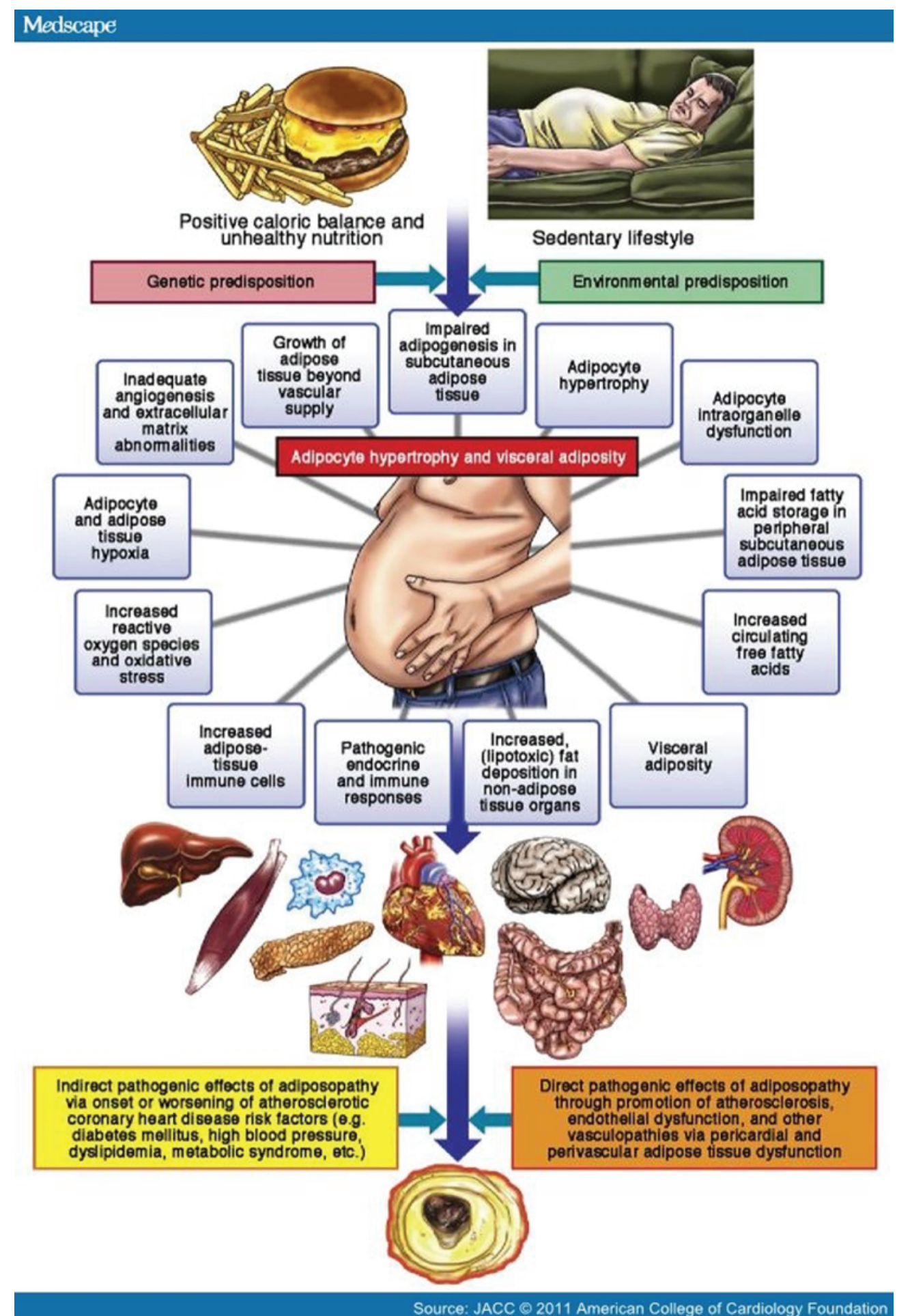

Figure 4. Adiposopathy: simplified relationship between pathogenic adipose tissue and cardiovascular disease.(21) (Adapted with permission from Elsevier Inc.) 
hormones, immune molecules, proteins, and other factors. (6) Derangements in adipose tissue endocrine and immune processes contribute to metabolic disease.(53) Pericardial and perivascular adiposopathy may have direct pathogenic effects on the myocardium, coronary arteries, and peripheral vessels via dysregulated local secretion of vasoactive and inflammatory factors that may contribute to atheroma instability and other cardiovascular pathophysiology.(5761)

Although adipocyte and adipose tissue dysfunction are often etiologic, adiposopathy alone does not cause or worsen metabolic disease. Instead, the clinical consequences of "sick fat" depend on how adipose tissue interacts or undergoes "cross talk" with other body organs such as the liver, muscle, pancreas, as well as organs of the cardiovascular, endocrine, immune, nervous, genitourinary, gastrointestinal, integumentary, and other body systems. (62) In summary, fat weight gain leading to metabolic disease is most dependent upon how fat is stored (adipocyte hypertrophy vs. adipocyte proliferation), where the fat is stored (visceral vs. other fat depots), and adipose tissue signalling and interactions with other body organs.

Various obesity paradoxes are described when increased body fat mass does not increase morbidity or mortality, when a decrease in excessive body fat does not improve patient health, or when an increase in body fat mass actually reduces morbidity or mortality. Many of these apparent clinical contradictions are mitigated if the pathogenic potential of excess adipose tissue is assessed not solely by adiposity, but also by adiposopathy. This also helps explain paradoxical populations described as "metabolically healthy, but obese", "metabolically obese, normal weight"(7), and the increased risk of T2DM among Pima Indians(6,63). Adiposopathy also helps explain the otherwise curious (paradoxical) use of "ectopic fat" to describe excessive fat deposition in any body organ, including increased fat deposition in fat depots (e.g., visceral adipose tissue)(64-66) and helps identify when adiposity or obesity might best be considered a disease $(9,67,68)$.

The adipocentric paradigm provides the basis for a unifying, pathophysiological process whereby fat gain in susceptible patients leads to fat dysfunction ('sick fat'), and wherein pathological abnormalities in fat function (adiposopathy) are more directly related to the onset of excessive fat related metabolic diseases (EFRMD) than increases in fat mass (adiposity) alone. But just as worsening fat function worsens EFRMD, improved fat function improves EFRMD. Peroxisome proliferatoractivated receptor-gamma agonists increase the recruitment, proliferation and differentiation of preadipocytes ('healthy fat') and cause apoptosis of hypertrophic and dysfunctional (including visceral) adipocytes resulting in improved fat function and improved metabolic parameters associated with EFRMD.(69)

\section{Adiposopathy: Replacing the Term "Metabolic Syndrome"}

Many authors and scientific organizations have characterized and applied terminology to the constellation of metabolic abnormalities often associated with the accumulation of excessive body fat. Unfortunately, not everyone agrees on any particular characterization, nor do they always agree upon the definition. The most common current term that refers to the cluster of metabolic abnormalities associated with disorders in glucose metabolism, hypertension and dyslipidemia is the 'metabolic syndrome'. A similar clinical presentation has also been termed atherothrombogenic syndrome, cardiovascular metabolic syndrome, deadly quartet (obesity, hyperinsulinemia, hypertension and dyslipidemia), dysmetabolic syndrome, syndrome $\mathrm{X}$, insulin resistance syndrome. The variety of different terms for a similar or related condition reflects the difficulty in applying one name to a constellation of related, and sometimes unrelated metabolic abnormalities, and reflects an unsatisfying attempt to identify one root pathophysiologic cause of all of these. Given the enormity of this disease burden and the known public health consequences, it would seem reasonable that extraordinary efforts be made towards preventing, treating, and potentially curing the metabolic syndrome. However, the conduct and reporting of clinical trials to demonstrate efficacy in the treatment of the metabolic syndrome have been hampered by the lack of consistent terminology, the lack of uniform diagnostic definitions and the different criteria reported in different clinical studies.(11)

Further complicating the matter is that not all clinicians are clear on the similarities and differences between the metabolic syndrome and other associated conditions. Not all clinicians are aware that patients with T2DM may or may not have metabolic syndrome, and patients with metabolic syndrome may or may not have diabetes. Moreover, even researchers are not certain whether insulin resistance syndrome and metabolic syndrome are the same, or have the same treatment goals.(70) It is also noteworthy that the scientific organizations that have defined metabolic syndrome have not required that the components of the metabolic syndrome be due to any unifying and underlying metabolic process. This lack of indication criteria for the treatment of the metabolic syndrome impairs 
the development of pharmaceutical agents to treat the underlying root cause and/or pathophysiology, and instead promotes continued research efforts focusing on drug treatment for the components of the metabolic syndrome. Accumulating scientific data suggest that in most patients, it is the dysfunction of adipose tissue (adiposopathy) that is the root mechanistic aetiology of abnormalities of glucose metabolism, blood pressure and lipid metabolism.(11)

If it becomes generally accepted that dysfunction of adipose tissue is the root mechanistic pathophysiologic aetiology of the metabolic abnormalities that compose the metabolic syndrome in the majority of patients, then it may be time to replace the term metabolic syndrome (a term largely reflective of sometimes unrelated consequence), and replace it with 'adiposopathy' (a term more focused on unified underlying causality). It may then be time to focus on adiposopathy as a primary treatment target, and to establish clear criteria for its diagnosis, and for granting an indication for its treatment.(11)

\section{Conclusion}

Adipocyte hypertrophy and visceral adiposity may contribute ("cause") metabolic diseases such as T2DM, hypertension, and dyslipidemia. Adiposopathy and "sick fat" are scientific and clinical terms, respectively, that help define when excessive body fat is a metabolic and cadiovascular disease.

\section{References}

1. World Health Organization. Global Strategy on Diet, Physical Activity and Health. [cited February 2008]. Available from: http://www. who.int/dietphysicalactivity/publications/facts/obesity/en/.

2. Bays HE, Chapman RH, Grandy S. The relationship of body mass index to diabetes mellitus, hypertension and dyslipidaemia: comparison of data from two national surveys. Int J Clin Pract. 2007; 61: 737-47.

3. Ford ES. Prevalence of the metabolic syndrome defined by the International Diabetes Federation among adults in the U.S. Diab Care. 2005; 28: 2745-9.

4. Yusuf S, Hawken S, Ounpuu S, Bautista L, Franzosi MG, Commerford $\mathrm{P}$, et al. Obesity and the risk of myocardial infarction in 27,000 participants from 52 countries : a case control study. Lancet. 2005; 366: $1640-9$

5. Executive summary of the third report of The National Cholesterol Education Program (NCEP) Expert Panel on detection, evaluation, and treatment of high blood cholesterol in adults (Adult Treatment Panel III). JAMA. 2001; 285: 2486-97.

6. Bays HE, Gonzalez-Campoy JM, Bray GA, Kitabchi AE, Bergman $\mathrm{DA}$, Schorr AB, et al. Pathogenic potential of adipose tissue and metabolic consequences of adipocyte hypertrophy and increased visceral adiposity. Expert Rev Cardiovasc Ther. 2008; 3: 343-68.

7. Karelis AD, St-Pierre DH, Conus F, Rabasa-Lhoret R, Poehlman ET. Metabolic and body composition factors in subgroups of obesity: what do we know? J Clin Endocrinol Metab. 2004; 89: 2569-75.

8. Bays HE, Dujovne CA. Adiposopathy is a more rational treatment target for metabolic disease than obesity alone. Curr Atheroscler Rep. 2006; 8: 144-56.

9. Bays HE, González-Campoy JM, Henry RR, Bergman DA, Kitabchi $\mathrm{AE}$, Schorr $\mathrm{AB}$, et al. Is adiposopathy (sick fat) an endocrine disease?. Int J Clin Pract. 2008; 10: 1474-83.

10. Hajer GR, Van Haeften TW, Visseren FLJ. Adipose tissue dysfunction in obesity, diabetes, and vascular diseases. Eur Heart J. 2008; 29: 2959-71.

11. Bays HE, Abate N, Chandalia M. Adiposopathy: sick fat causes high blood sugar, high blood pressure, and dyslipidemia. Future Cardiol. 2005; 1: 39-59.

12. Lavie CJ, Milani RV, Ventura HO. Obesity and cardiovascular disease : risk factor, paradox, and impact of weight loss. J Am Coll Cardiol. 2009; 53: 1925-32.

13. de Ferranti S, Mozaffarian D. The perfect storm: obesity, adipocyte dysfunction, and metabolic consequences. Clin Chem. 2008; 54: 945-55.

14. Schäffler A, Müller-Ladner U, Schölmerich J, Büchler C. Role of adipose tissue as an inflammatory organ in human diseases. Endocr Rev. 2006; 27: 449-67.

15. Shimomura I, Funahashi T, Takahashi M, Maeda K, Kotani K, Nakamura T, et al. Enhanced expression of PAI-1 in visceral fat: possible contributor to vascular disease in obesity. Nat Med. 1996; 2: 800-3.

16. Poirier P, Giles TD, Bray GA, Hong Y, Stern JS, Pi-Sunyer FX, et al. Obesity and cardiovascular disease: pathophysiology, evaluation, and effect of weight loss: an update of the 1997 American Heart Association Scientific Statement on Obesity and Heart Disease from the Obesity Committee of the Council on Nutrition, Physical Activity, and Metabolism Circulation. 2006;113:898-918.

17. Tchoukalova YD, Koutsari C, Votruba SB, Tchkonia T, Giorgadze $\mathrm{N}$, Thomou T, et al. Sex and depot-dependent differences in adipogenesis in normal-weight humans. Obesity. 2010; 18:187580.

18. Bloomgarden ZT. World Congress on the insulin resistance syndrome, 2009: cellular mechanisms of insulin resistance. Diab Care. 2010; 33: e103-8.

19. Spalding KL, Arner E, Westermark PO, Bernard S, Buchholz BA, Bergmann $\mathrm{O}$, et al. Dynamics of fat cell turnover in humans. Nature. 2008; 453: 783-7.

20. Heilbronn L, Smith SR, Ravussin E. Failure of fat cell proliferation, mitochondrial function and fat oxidation results in ectopic fat storage, insulin resistance and type II diabetes mellitus. Int J Obes Relat Metab Disord. 2004; 28: S12-21.

21. Bays HE. Adiposopathy: is "sick fat" a cardiovascular disease?. J Am Coll Cardiol. 2011; 57: 2461-73.

22. Brook CG, Lloyd JK, Wolf OH. Relation between age of onset of obesity and size and number of adipose cells. Br Med J. 1972; 2: 25-7.

23. Helmlinger G, Yuan F, Dellian M, Jain RK. Interstitial pH and pO2 gradients in solid tumors in vivo: high-resolution measurements reveal a lack of correlation. Nat Med. 1997; 3: 177-82.

24. Hosogai N, Fukuhara A, Oshima K, Miyata Y, Tanaka S, Segawa $\mathrm{K}$, et al. Adipose tissue hypoxia in obesity and its impact on adipocytokine dysregulation. Diabetes. 2007; 56: 901-11.

25. Semenza GL. Surviving ischemia: adaptive responses mediated by hypoxiainducible factor 1. J Clin Invest. 2000; 106: 809-12.

26. Mori K. Tripartite management of unfolded proteins in the endoplasmic reticulum. Cell. 2000; 101: 451-4.

27. Gregor MF, Hotamisligil GS. Thematic review series: Adipocyte Biology. Adipocyte stress: the endoplasmic reticulum and metabolic disease. J Lipid Res. 2007; 48: 1905-14. 
28. Ravussin E, Smith SR. Increased fat intake, impaired fat oxidation, and failure of fat cell proliferation result in ectopic fat storage, insulin resistance, and type 2 diabetes mellitus. Ann N Y Acad Sci. 2002; 967: 363-78.

29. Pasarica M, Xie H, Hymel D, Bray G, Greenway F, Ravussin E, et al. Lower total adipocyte number but no evidence for small adipocyte depletion in patients with type 2 diabetes. Diab Care. 2009; 32: 900-2.

30. McLaughlin T, Sherman A, Tsao P, Gonzalez O, Yee G, Lamendola $\mathrm{C}$, et al. Enhanced proportion of small adipose cells in insulinresistant vs insulin-sensitive obese individuals implicates impaired adipogenesis. Diabetologia. 2007; 50: 1707-15.

31. Danforth Jr E. Failure of adipocyte differentiation causes type II diabetes mellitus? Nat Genet. 2000; 26: 13.

32. Adams KF, Schatzkin A, Harris TB, Kipnis V, Mouw T, BallardBarbash R, et al. Overweight, obesity, and mortality in a large prospective cohort of persons 50 to 71 years old. N Engl J Med. 2006; 355: 763-78.

33. Pischon T, Boeing H, Hoffmann K, Bergmann M, Schulze MB, Overvad K, et al. General and abdominal adiposity and risk of death in Europe. N Engl J Med. 2008; 359: 2105-20.

34. Uretsky S, Messerli FH, Bangalore S, Champion A, Cooper-Dehoff RM, Zhou Q, et al. Obesity paradox in patients with hypertension and coronary artery disease. Am J Med. 2007; 120: 863-70.

35. Buettner HJ, Mueller C, Gick M, Ferenc M, Allgeier J, Comberg T, et al. The impact of obesity on mortality in UA/non-ST-segment elevation myocardial infarction. Eur Heart J. 2007; 28: 1694-701.

36. Johnson NP, Wu E, Bonow RO, Holly TA. Relation of exercise capacity and body mass index to mortality in patients with intermediate to high risk of coronary artery disease. Am J Cadiol. 2008; 102: 102833 .

37. Wassertheil-Smoller S, Fann C, Allman RM, Black HR, Camel GH, Davis B, et al., Relation of low body mass to death and stroke in the systolic hypertension in the elderly program. The SHEP Cooperative Research Group. Arch Intern Med. 2000; 160: 494-500.

38. Stamler R, Ford CE, Stamler J. Why do lean hypertensive patients have higher mortality rates than other hypertensive patients? Findings of the hypertension detection and follow-up program. Hypertension. 1991; 17: 553-64.

39. Tuomilehto J. Body mass index and prognosis in elderly hypertensive patients: a report from the European Working Party on High Blood Pressure in the Elderly. Am J Med. 1991; 90: 34S-41S.

40. Lavie CJ, Milani RV, Ventura HO. Obesity, heart disease, and favorable prognosis truth or paradox? Am J Med. 2007; 120: 825-6.

41. Kenchaiah S, Evans JC, Levy D, Wilson PW, Benjamin EJ, Larson MG, et al. Obesity and the risk of heart failure. N Engl J Med 2002; 347: 305-13.

42. Horwich TB, Fonarow GC, Hamilton MA, MacLellan WR, Woo MA, Tillisch JH. The relationship between obesity and mortality in patients with heart failure. J Am Coll Cardiol 2001; 38: 789-95.

43. Oreopoulos A, Padwal R, Kalantar-Zadeh K, Fonarow GC, Norris CM, McAlister FA. Body mass index and mortality in heart failure: a meta-analysis. Am Heart J 2008; 156: 13-22.

44. Lavie CJ, Milani RV. Obesity and cardiovascular disease: the Hippocrates paradox? J Am Coll Cardiol. 2003; 42: 677-9.

45. Hubert HB, Feinleib M, McNamara PM, Castelli WP. Obesity as an independent risk factor for cardiovascular disease: a 26-year followup of participants in the Framingham Heart Study. Circulation. 1983; 67: 968-77.

46. Lavie CJ, Milani RV. Cardiac rehabilitation and exercise training programs in metabolic syndrome and diabetes. J Cardiopulm Rehabil. 2005; 25: 59-66.

47. Romero-Corral A, Montori VM, Somers VK, Korinek J, Thomas RJ, Allison TG, et al. Association of bodyweight with total mortality and with cardiovascular events in coronary artery disease: a systematic review of cohort studies. Lancet. 2006; 368: 666-78.

48. McAuley P, Myers J, Abella J, Froelicher V. Body mass, fitness and survival in veteran atients: another obesity paradox?. Am J Med. 2007; 120: 518-24.

49. Galal W, van Gestel YR, Hoeks SE, Sin DD, Winkel TA, Bax JJ, et $a l$. The obesity paradox in patients with peripheral arterial disease: the influence of chronic obstructive pulmonary disease. Chest 2009; 134:925-30.

50. Rasouli N, Kern PA. Adipocytokines and the metabolic complications of obesity. J Clin Endocrinol Metab. 2008: 93: S64-S73.

51. Andreotti F, Rio T, Lavorgna A. Body fat and cardiovascular risk: understanding the obesity paradox. Eur Heart J. 2009; 30: 752-4.

52. Mak K-H, Bhatt DL, Shao M, Haffner SM, Hamm CW, Hankey GJ, et al. The influence of body mass index on mortality and bleeding among patients with or at high-risk of atherothrombotic disease. Eur Heart J 2009; 30: 857-65.

53. Bays HE, Ballantyne C. Adiposopathy: why do adiposity and obesity cause metabolic disease?. Future Lipidol. 2006; 1: 389-420.

54. Kershaw EE, Flier JS. Adipose tissue as an endocrine organ. J Clin Endocrinol Metab. 2004; 89: 2548-56.

55. Bays HE, Rodbard RW, Schorr AB, González-Campoy JM. Adipoosopathy : treating pathogenic adipose tissue to reduce cardiovascular disease risk. Curr Treat Option Cardiovasc Med. 2007; 9: 259-71.

56. Bays HE. Adiposopathy, metabolic syndrome, quantum physics, general relativity, chaos and the Theory of Everything. Expert Rev Cardiovasc Ther. 2005; 3: 393-404.

57. Higuchi ML, Gutierrez PS, Bezerra HG, Palomino SA, Aiello VD, Silvestre JM, et al. Comparison between adventitial and intimal inflammation of ruptured and nonruptured atherosclerotic plaques in human coronary arteries. Arq Bras Cardiol. 2002; 79 :20-4

58. Baker AR, Silva NF, Quinn DW, Harte AL, Pagano D, Bonser RS, et al. Human epicardial adipose tissue expresses a pathogenic profile of adipocytokines in patients with cardiovascular disease. Cardiovasc Diabetol. 2006; 5:1.

59. Mazurek T, Zhang L, Zalewski A, Mannion JD, Diehl JT, Arafat H, et al. Human epicardial adipose tissue is a source of inflammatory mediators. Circulation. 2003; 108: 2460-6.

60. Torriani M, Grinspoon S. Racial differences in fat distribution: the importance of intermuscular fat. Am J Clin Nutr. 2005; 81: 731-2.

61. Engeli S. Is there a pathophysiological role for perivascular adipocytes? Am J Physiol Heart Circ Physiol. 2005; 289: H1794-5.

62. Bays HE. "Sick fat," metabolic disease, and atherosclerosis. Am J Med. 2009; 122: S26-37.

63. Weyer C, Foley JE, Bogardus C, Tataranni PA, Pratley RE. Enlarged subcutaneous abdominal adipocyte size, but not obesity itself, predicts type II diabetes independent of insulin resistance. Diabetologia. 2000; 43: 1498-506.

64. Bays H, Mandarino L, DeFronzo RA. Role of the adipocyte, free fatty acids, and ectopic fat in pathogenesis of type 2 diabetes mellitus: peroxisomal proliferator-activated receptor agonists provide a rational therapeutic approach. J Clin Endocrinol Metab. 2004; 89: 463-78.

65. Bays H. Phentermine, topiramate and their combination for the treatment of adiposopathy ('sick fat') and metabolic disease. Expert Rev Cardiovasc Ther. 2010; 8: 1777-801.

66. Smith U. Visceral fat, like epicardial fat, is an ectopic fat depot which reflects cardiometabolic risk on obesity. J Inter Chair Cardiometab Risk. 2008; 1: 17-9.

67. Lewis CE, McTigue KM, Burke LE, Poirier P, Eckel RH, Howard $\mathrm{BV}$, et al. Mortality, health outcomes, and body mass index in the overweight range: a science advisory from the American Heart Association. Circulation. 2009; 119: 3263-71. 
68. Lawlor DA, Hart CL, Hole DJ, Davey Smith G. Reverse causality and confounding and the associations of overweight and obesity with mortality. Obesity (Silver Spring). 2006; 14: 2294-304.

69. Bays H, Blonde L, Rosenson R. Adiposopathy: how do diet, exercise and weight loss drug therapies improve metabolic disease in overweight patients? Expert Rev Cardiovasc Ther. 2006; 4: 871-95.

70. Reaven $\mathrm{G}$. The metabolic syndrome or the insulin resistance syndrome? Different names, different concepts, and different goals. Endocrinol Metab Clin North Am. 2004; 33: 283-303. 